Revista Brasileira de Farmacognosia Brazilian Journal of Pharmacognosy 22(5): 1104-1110, Sep./Oct. 2012

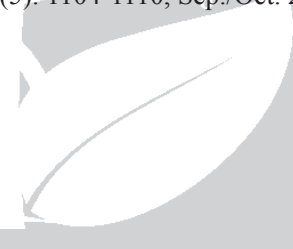

Article

Received 25 Feb 2012

Accepted 17 May 2012

Available online 17 Jul 2012

Keywords:

acute toxicity

Brazilian arnica

histopathological analysis

Lychnophora trichocarpha

ISSN 0102-695X

http://dx.doi.org/10.1590/S0102-

695X2012005000089

\section{Toxicological evaluation of ethanolic extract of Lychnophora trichocarpha, Brazilian arnica}

\author{
Fernanda C. Ferrari, ${ }^{1}$ Andrea Grabe-Guimarães, ${ }^{2}$ Cláudia M. \\ Carneiro, ${ }^{3}$ Maíra R. de Souza, ${ }^{1}$ Leidiane C. Ferreira, ${ }^{1}$ Tânia T. \\ de Oliveira, ${ }^{4}$ Dênia A. Saúde-Guimarães ${ }^{* 1}$
}

\author{
${ }^{1}$ Laboratório de Plantas Medicinais, Escola de Farmácia, Universidade Federal \\ de Ouro Preto, Brazil, \\ ${ }^{2}$ Laboratório de Farmacologia Experimental, Escola de Farmácia, Universidade \\ Federal de Ouro Preto, Brazil, \\ ${ }^{3}$ Laboratório de Imunopatologia, Núcleo de Pesquisas em Ciências Biológicas, \\ Universidade Federal de Ouro Preto, Brazil, \\ ${ }^{4}$ Laboratório de Biofármacos, Universidade Federal de Viçosa, Brazil.
}

\begin{abstract}
The species of the genus Lychnophora, Asteraceae, are popularly known as "arnica" and are native from Brazilian savana (Cerrado). They are widely used in Brazilian folk medicine as anti-inflammatory, to treat bruise, pain, rheumatism and for insect bites. For evaluation of acute toxicity, the ethanolic extract was given to albino female and male mice. In open-field test, the extract of Lychnophora trichocarpha (Spreng.) Spreng. $(0.750 \mathrm{~g} / \mathrm{kg})$ induced a significant inhibition of the spontaneous locomotor activity and exploratory behavior of the animals were observed 1 and $4 \mathrm{~h}$ after administration. In traction test, the same dose reduced the muscular force $1 \mathrm{~h}$ after administration. The exploratory behavior reduced significantly in the group that received $0.50 \mathrm{~g} / \mathrm{kg}, 1$ and $4 \mathrm{~h}$ after administration of the extract. The animals that received the doses of $0.25,0.50$ and $0.75 \mathrm{~g} / \mathrm{kg} \mathrm{did}$ not show any change of blood biochemical parameters comparing to control group and showed some histopathological changes such as congestion and inflammation of kidney and liver. The dose of $1.5 \mathrm{~g} / \mathrm{kg}$ caused the most serious signs of toxicity. Histopathological changes observed was hemorrhage in $62.5 \%$ and pulmonary congestion in $100 \%$ of the animals. Brain and liver congestion was found in $62.5 \%$ of the animals.
\end{abstract}

\section{Introduction}

Medicinal plants are often used without satisfactory demonstration of their pharmacological activities. Moreover, many people believe that traditional medicines have no adverse effects. In fact, the adverse effects of phytomedicines, as well as its adulteration, toxicity, and drug interaction are common problems related to public health (Veiga et al., 2005).

There are few studies evaluating Lychnophora, Asteraceae, species toxicity. A reduction on the spontaneous locomotion was observed after the oral administration of the hydroalcoholic extract of $L$. ericoides (Cerqueira et al., 1987; Guzzo et al., 2006). No activity was observed on the muscle tone for the hydroalcoholic extract of L. pinaster (Azevedo, 2004). $L$. trichocarpha and $L$. ericoides extracts were able to reduce the exploratory capacity in mice (Guzzo et al., 2006).
A study carried out by Ferraz-Filha (2012) evaluated the cytotoxicity of five species of Lychnophora on Artemia salina and the crude ethanolic extract of $L$. trichocarpha showed mildly cytotoxic $\left(\mathrm{LC}_{50}=672.38 \mu \mathrm{g}\right.$ / $\mathrm{mL})$.

Sesquiterpene lactones, components of Lycnophora species, are known for their cytotoxic and antitumoral activity (Kupchan et al., 1971). Lychnopholide, present in L. trichocarpha, is potentially cytotoxic (Saúde-Guimarães, 1998; Canalle et al., 2001). The species Arnica montana, which is also rich in sesquiterpene lactones, has been associated to numerous cases of dermatitis of toxic or allergic origin (Hörmann \& Korting, 1995). Considering the great importance of further evaluation of general toxicity of plants popularly used such as Lycnophora species, the aim of this study was to evaluate the safety of the use of L. trichocarpha, when administered acutely and systemically in mice. 


\section{Material and Methods}

\section{Plant material}

Aerial parts of Lychnopora trichocarpha (Spreng.) Spreng., Asteraceae, were collected in August 2006, in Minas Gerais, Brazil. Voucher specimens were deposited at the Instituto de Ciências Exatas e Biológicas of Universidade Federal de Ouro Preto, reference number 20635. The plant species was collected with the permission of Instituto Brasileiro do Meio Ambiente e dos Recursos Naturais Renováveis (IBAMA-license no 009/2006)

\section{Preparation of plant extracts}

Aerial parts of L. trichocarpha $(1.9 \mathrm{~kg})$ were air-dried, reduced to powder and extracted with ethanol, at the room temperature, for two weeks. The solvent was removed under reduced pressure and temperature below $40{ }^{\circ} \mathrm{C}$ to yield the dried crude ethanolic extracts $(361.0 \mathrm{~g})$. The crude ethanolic extract was dissolved in dimethylsulfoxide (DMSO), Tween 80 and distilled water (1:1:8), to give the concentrations of $25,50,75$, 112.5 and $150 \mathrm{~g} / \mathrm{mL}$, in order to allow the administration of $0.05 \mathrm{~mL}$ at most, which corresponds to the doses of $0.25 ; 0.50 ; 0.75 ; 1.125$ and $1.50 \mathrm{~g} / \mathrm{kg}$, respectively.

\section{Animals}

Swiss albino mice (25-30 g), of either sex were used. The animals were maintained on a 12/12 h light: dark cycle with a standard pellet diet and clean drinking water ad libitum. Ethical Committee of Universidade Federal de Ouro Preto approved the experimental protocol $\left(\mathrm{n}^{\circ} 06 / 2009\right)$ and it is in accordance to the Guide for the Care and Use of Laboratory Animals, published by the US National Institute of Health (NIH Publication, revised in 1985).

\section{Short-term toxicity evaluation}

To determine the short-term toxicity of the extract, the plant extracts were administered at 0.25 , 0.50 and $0.75 \mathrm{~g} / \mathrm{kg}$, being one dose for each group. Both female and male mice were distributed into six animals groups of and each animal received one single dose by intraperitoneal (i.p.) route. Control groups received only the vehicle (DMSO-Tween-water). General behavior as locomotion, exploratory ability and muscle tone, of the animals were determined for fourteen days, as described below for each test. At the $15^{\text {th }}$ day, the animals were anesthetized with sodium pentobarbital $(30 \mathrm{mg} / \mathrm{kg}$, i.p.) and blood sample was obtained from each animal in order to determine biochemical parameters. The liver and kidneys were dissected out, washed with saline and conserved in formalin (10\%) for histological analysis a posteriori.

A second experimental protocol was carried out using a higher dose of the extract $(1.5 \mathrm{~g} / \mathrm{kg}$, i.p. $)$. The control group received only the vehicle. Two hours after extract administration the animals were submitted to a cervical displacement. The heart, liver, kidneys, lungs, whole brain and parts of small intestine were dissected out, washed with saline and conserved in formalin $(10 \%)$ for histological analysis a posteriori. No other tests were carried out in animals that received the dose of $1.5 \mathrm{~g} / \mathrm{kg}$, only histological changes.

The experimental protocols were carried out according to the Anvisa (2004) specifications.

\section{Locomotion and muscle tone evaluation}

\section{Open field method}

It was used the open-field method described by Turner (1972), that evaluates the spontaneous locomotion and the exploratory ability of animals. Each mouse was maintained in the open-field apparatus for 5 min. The number of squares walked by the animal and the number of rearing during this period were recorded. The animals were submitted to the open field test at 0 , $1,4,24 \mathrm{~h} ; 7$ and 14 days after the single dose extract administration.

\section{Traction method}

The traction test was performed according to the method described by Rudzik et al. (1973) in order to evaluate muscle tone alterations. Each animal was placed individually on the apparatus on forefeet and was observed for the ability to put one hind paw on the wire up to $5 \mathrm{~s}$. The test was conducted at the same times mentioned above for the open field test.

\section{Blood biochemical parameters evaluation}

Blood samples without anticoagulant were centrifuged (1000 rpm, $30 \mathrm{~min}$ ) and the obtained serum was kept at $-4{ }^{\circ} \mathrm{C}$ for four days, at most, before the biochemical parameters determination.

Serum creatinine, urea, uric acid, total protein, alanine aminotransferase (ALT), aspartate aminotransferase (AST) and alkaline phosphatase were determined. Creatinine and total proteins were measured by colorimetric assay, while the other parameters were measured by enzymatic colorimetric assay. The kits used in these tests were obtained from Bioclin ${ }^{\circledR}$ (Brazil) and the analysis were carried out using a Multiparametric Autoanalyser (Lisabio B652, USA). 


\section{Microscopic examination}

Heart, liver, kidneys, lungs, brain and pieces of small intestine were conserved in $10 \%$ formol/saline for histopathological studies. Tissues were processed by conventional techniques. The paraffine embedded sections of 4-5 $\mu \mathrm{m}$ thickness were prepared with the rotary microtome, stained with hematoxylin and eosin for microscopic examination using optical Microscope (Leica, DM5000, Germany) linked to a computer for pictures processing.

\section{Statistical analysis}

Results were presented as mean $\pm \mathrm{SEM}$ for at least six independent experiments. Statistical evaluation was done using one-way analysis of variance (ANOVA), followed by Dunnett's test. To evaluate the results obtained from the open field method, Student's $t$ test was used. Results obtained from traction method were evaluated using Fischer's test. $p$-values $\leq 0.05$ were taken to indicate statistical significance. The Software GrafPad Prism 4.0 was used for analyses.

\section{Results}

Locomotion and muscle tone evaluation

The results presented in Table 1 show that Lychnopora trichocarpha (Spreng.) Spreng., Asteraceae, ethanolic extract at doses 0.25 and $0.50 \mathrm{~g} /$ $\mathrm{kg}$ did not change significantly the locomotion of the animals in the open field method. However, the animals that received the dose $0.75 \mathrm{~g} / \mathrm{kg}$ presented locomotion reduction at 1 and $4 \mathrm{~h}$ after administration of the extract (35.8 \pm 8.32 and $37.5 \pm 7.00$ squares $/ 5$ min, respectively), when compared to time 0 , before administration of the extract (87.2 \pm 7.73$)$.

Data presented in Table 2 show that $L$. tricocarpha at dose of $0.25 \mathrm{~g} / \mathrm{kg}$, did not reduce the rearing. The group that received $0.50 \mathrm{~g} / \mathrm{kg}$ presented a significant reduction of rearing number at 1 and $4 \mathrm{~h}$ after administration of the extract (7.2 \pm 1.85 and $5.3 \pm 1.41)$, when compared to time prior to the administration (20.9 \pm 5.54$)$. The group treated with $0.75 \mathrm{~g} / \mathrm{kg}$ also presented reduction of rearing number at 1 and $4 \mathrm{~h}$ after administration of the extract (2.1 \pm 1.10 and $1.6 \pm 0.70$, respectively), compared to time

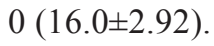

The traction method was used to investigate muscle tone in vivo alterations caused by L. trichocarpha extract comparing to the control group that had a normal response in the tests. Only the group that received 0.75 $\mathrm{g} / \mathrm{kg}$ presented a significant reduction (Table 3$), 1 \mathrm{~h}$ after administration of the extract $(50 \%$ of animals failed the test), in relation to time 0 (no animals failed the test). Similar results were found for the dose level of 0.25 at 24 h post test and $41.67 \%$ at fourteen days.

Table 1. Effect of crude ethanol extract of Lychnophora trichocarpha on the number of squares covered by the animals in the open field.

\begin{tabular}{ccccc}
\hline Time & Control & $0.25 \mathrm{~g} / \mathrm{kg}$ & $0.50 \mathrm{~g} / \mathrm{kg}$ & $0.75 \mathrm{~g} / \mathrm{kg}$ \\
\hline 0 hour & $99.75 \pm 10.16$ & $90.08 \pm 11.10$ & $73.67 \pm 8.71$ & $87.18 \pm 7.73$ \\
1 hour & $78.33 \pm 6.90$ & $70.83 \pm 4.83$ & $65.83 \pm 10.08$ & $35.83 \pm 8.32^{*}$ \\
4 hour & $75.57 \pm 6.76$ & $64.25 \pm 8.97$ & $57.33 \pm 9.11$ & $37.45 \pm 7.00^{*}$ \\
24 hour & $70.78 \pm 9.71$ & $81.58 \pm 11.18$ & $83.92 \pm 8.31$ & $82.45 \pm 9.21$ \\
7 days & $77.29 \pm 12.97$ & $80.08 \pm 8.61$ & $90.08 \pm 7.26$ & $88.00 \pm 11.61$ \\
14 days & $77.56 \pm 11.31$ & $76.67 \pm 10.28$ & $86.42 \pm 7.05$ & $72.27 \pm 10.94$ \\
\hline
\end{tabular}

Values represent mean \pm SEM, $\mathrm{n}=12$ animals. ${ }^{*} p \leq 0.05$ compared to time 0 ( $\mathrm{t}$ test).

Table 2. Effect of crude ethanol extract of Lychnophora trichocarpha on the number of rearing in the open field test.

\begin{tabular}{ccccc}
\hline Time & Control & $0.25 \mathrm{~g} / \mathrm{kg}$ & $0.50 \mathrm{~g} / \mathrm{kg}$ & $0.75 \mathrm{~g} / \mathrm{kg}$ \\
\hline 0 hour & $99.75 \pm 10.16$ & $90.08 \pm 11.10$ & $73.67 \pm 8.71$ & $87.18 \pm 7.73$ \\
1 hour & $78.33 \pm 6.90$ & $70.83 \pm 4.83$ & $65.83 \pm 10.08$ & $35.83 \pm 8.32 *$ \\
4 hour & $75.57 \pm 6.76$ & $64.25 \pm 8.97$ & $57.33 \pm 9.11$ & $37.45 \pm 7.00^{*}$ \\
24 hour & $70.78 \pm 9.71$ & $81.58 \pm 11.18$ & $83.92 \pm 8.31$ & $82.45 \pm 9.21$ \\
7 days & $77.29 \pm 12.97$ & $80.08 \pm 8.61$ & $90.08 \pm 7.26$ & $88.00 \pm 11.61$ \\
14 days & $77.56 \pm 11.31$ & $76.67 \pm 10.28$ & $86.42 \pm 7.05$ & $72.27 \pm 10.94$ \\
\hline
\end{tabular}

Values represent mean $\pm \mathrm{SEM}, \mathrm{n}=12$ animals. ${ }^{*} p \leq 0.05$ compared to time 0 (t test). 
Table 3. Effect of ethanol extract of Lychnophora trichocarpha on muscle strength in the traction method.

\begin{tabular}{ccccc}
\hline Time & Control & $0.25 \mathrm{~g} / \mathrm{kg}$ & $0.50 \mathrm{~g} / \mathrm{kg}$ & $0.75 \mathrm{~g} / \mathrm{kg}$ \\
\hline 0 hour & 0 & 0.25 & 0 & 0 \\
1 hour & 33.33 & 0.25 & 0 & $50.00^{*}$ \\
4 hour & 33.33 & 33.33 & 5.33 & 25.00 \\
24 hour & 25.00 & 33.33 & 16.67 & 16.67 \\
7 days & 16.67 & $41.67^{*}$ & 0 & 25.00 \\
14 days & 25.00 & 0 & 0.33 \\
\hline
\end{tabular}

The data represent the percentage of animals that failed the test. ${ }^{*} p \leq 0.05$ compared to time 0 (Fisher's test).

Table 4. Biochemical parameters obtained from the serum of mice treated with crude ethanolic extract of Lychnophora trichocarpha (i.p.) after fourteen days.

\begin{tabular}{ccccc}
\hline Dosage & Control & $0.25 \mathrm{~g} / \mathrm{kg}$ & $0.50 \mathrm{~g} / \mathrm{kg}$ & $0.75 \mathrm{~g} / \mathrm{kg}$ \\
\hline Urea $(\mathrm{mg} / \mathrm{dL})$ & $56.17 \pm 3.40$ & $51.92 \pm 3.36$ & $56.52 \pm 2.70$ & $64.08 \pm 2.20$ \\
Uric acid $(\mathrm{mg} / \mathrm{dL})$ & $2.60 \pm 0.24$ & $3.07 \pm 0.74$ & $2.69 \pm 0.20$ & $2.96 \pm 0.44$ \\
Creatinine $(\mathrm{mg} / \mathrm{dL})$ & $0.40 \pm 0.05$ & $0.37 \pm 0.02$ & $0.31 \pm 0.026$ & $0.40 \pm 0.05$ \\
\hline
\end{tabular}

Values represent mean \pm epm. $\mathrm{n}=12$ animals (ANOVA followed by Dunnett's test. considering differences significant when $p \leq 0.05$ ).

Table 5. Biochemical parameters obtained from the serum of mice treated with crude ethanolic extract of Lychnophora trichocarpha (i.p.) after fourteen days

\begin{tabular}{ccccc}
\hline Dosage & Control & $0.25 \mathrm{~g} / \mathrm{kg}$ & $0.50 \mathrm{~g} / \mathrm{kg}$ & $0.75 \mathrm{~g} / \mathrm{kg}$ \\
\hline AST (U/L) & $152.90 \pm 12.59$ & $122.80 \pm 10.70$ & $133.60 \pm 5.69$ & $178.90 \pm 17.88$ \\
ALT (U/L) & $93.73 \pm 14.02$ & $79.27 \pm 14.95$ & $74.55 \pm 11.28$ & $73.56 \pm 10.85$ \\
Alkaline phosphatase (U/L) & $174.70 \pm 9.06$ & $182.50 \pm 19.70$ & $224.00 \pm 18.06$ & $216.20 \pm 17.18$ \\
Total protein (mg/L) & $70.65 \pm 4.39$ & $64.55 \pm 2.66$ & $61.13 \pm 2.18$ & $64.40 \pm 2.89$ \\
\hline
\end{tabular}

Values represent mean \pm epm. $\mathrm{n}=12$ animals (ANOVA followed by Dunnett's test. considering differences significant when $p \leq 0.05$ ).

\section{Blood Biochemical parameters evaluation}

Serum parameters of treated animals $(0.25$, 0.50 and $0.75 \mathrm{~g} / \mathrm{kg}$ ) were similar to the control group.

Urea, uric acid and creatinine were measured in order to evaluate the potential toxicity of the extract to the kidneys. The group that received $0.75 \mathrm{~g} / \mathrm{kg}$ showed a slight, but not significant, increase in urea (Table 4). The results of aminotransferases (AST and ALT) and alkaline phosphatase of groups treated with $0.25,0.50$ and $0.75 \mathrm{~g} / \mathrm{kg}$ of extract were not statistically different from those found in control group (Table 5).

\section{Microscopic examination}

The histopathological evaluation $(n=6$, three males and three females) performed at doses $0.25,0.50$ and $0.75 \mathrm{~g} / \mathrm{kg}$, showed congestion and inflammation in kidneys and liver, regardless of the dose used, ranging from mild to moderate. Moreover, $55.6 \%$ of the animals presented glomerular loss. However, these events were subtle and were not enough to induce biochemical changes as described above, allowing the animals to survive without important loss function.
The photomicrograph shown in Figure 1 represents the general aspects of the liver and kidneys of animals that received $0.25,0.50$ and $0.75 \mathrm{~g} / \mathrm{kg}$ of extract, compared to the control group.

The histopathologic evaluation $(n=8$, four males and four females) performed for the dose of $1.50 \mathrm{~g} / \mathrm{kg}$ showed pulmonary bleeding in $62.5 \%$ and pulmonary congestion in $100 \%$ of animals. In brain and liver, congestion was found in $62.5 \%$ of the animals. The photomicrograph showed in Figure 2 represents the general aspects of brain and lung of animals that received $1.50 \mathrm{~g} / \mathrm{kg}$ of extract, compared to the control group.

\section{Discussion}

Aerial parts of Lychnopora trichocarpha (Spreng.) Spreng., Asteraceae, macerated in water, ethanol or "cachaça" (sugar cane spirit) are used by oral or topical route to treat inflammation, bruises, contusions, rheumatism and insect bites (Cerqueira et al., 1987; Guzzo et al., 2008; Saúde et al., 1998). The present study shows, acute toxic effects of $L$. trichocarpha in mice, after i.p. administration of its 


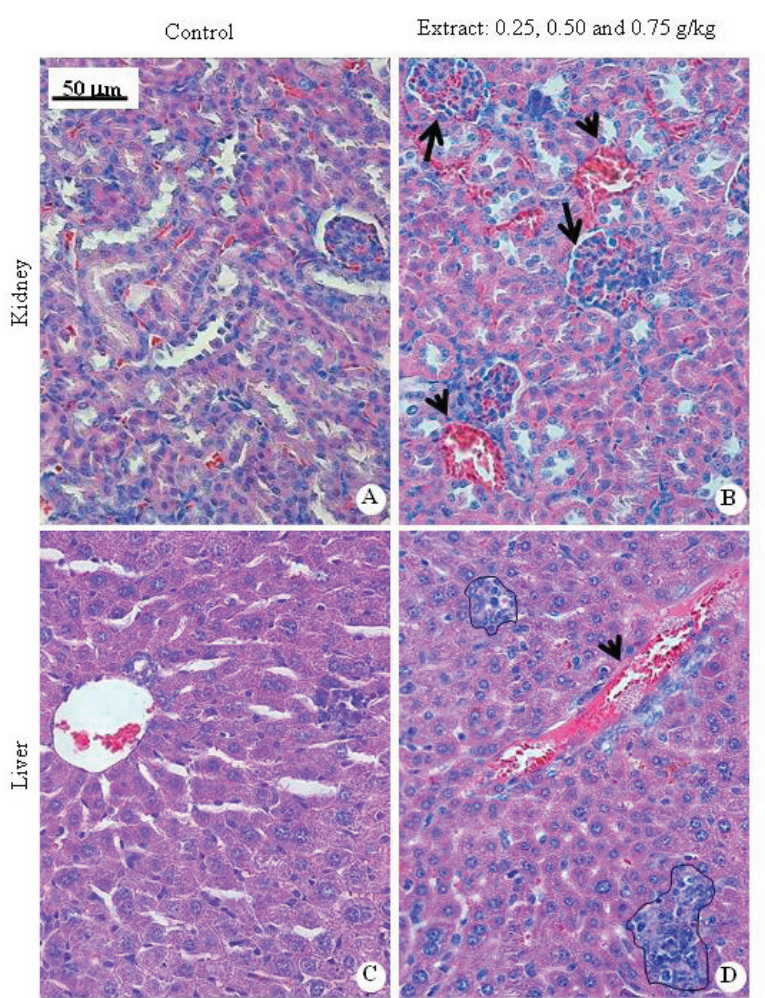

Figure 1. Photomicrographs of kidneys and livers sections of mice subjected to toxicity study of the crude ethanol extract of Lychnophora trichocarpha. A and C: control group showing normal histopathology; B and D: animals treated with $L$. trichocarpha showing glomerular congestion (arrows); renal and liver congestion (arrowheads); and mild inflammation (defined areas). Hematoxylin-eosin. $\mathrm{Bar}=50 \mu \mathrm{m}$.

crude ethanol extract.

Besides allowing the analysis of locomotion and exploratory capacity of the animals, the open-field method is also used to study emotional behavior (Prut \& Belzung, 2003; Denenberg, 1969). A decrease of squares number crossed or rearing number indicates a sedative effect and can be a useful parameter to assess anxiety in animals (Rodríguez et al., 1984). A decrease in spontaneous locomotion reflects a reduced excitability originating from the central nervous system (CNS) disturbes (Ozturk et al., 1996). Alterations of motor activity of mice can lead to incorrect results of certain responses, e.g. antinociception (Prut \& Belzung, 2003; Tjølsena et al., 1992). Thus, it is important to verify if $L$. trichocarpha has substances that can significantly affect the locomotion of the animal and thereby predict if these substances are able to reach the CNS by crossing the blood brain barrier. This way CNS effects can be considered as adverse effects or toxicity, and the absence of such effects of the plant species could indicate the safety of its use. A previous study with $L$. ericoides showed that mice treated with the hydroalcoholic extract of this species presented a

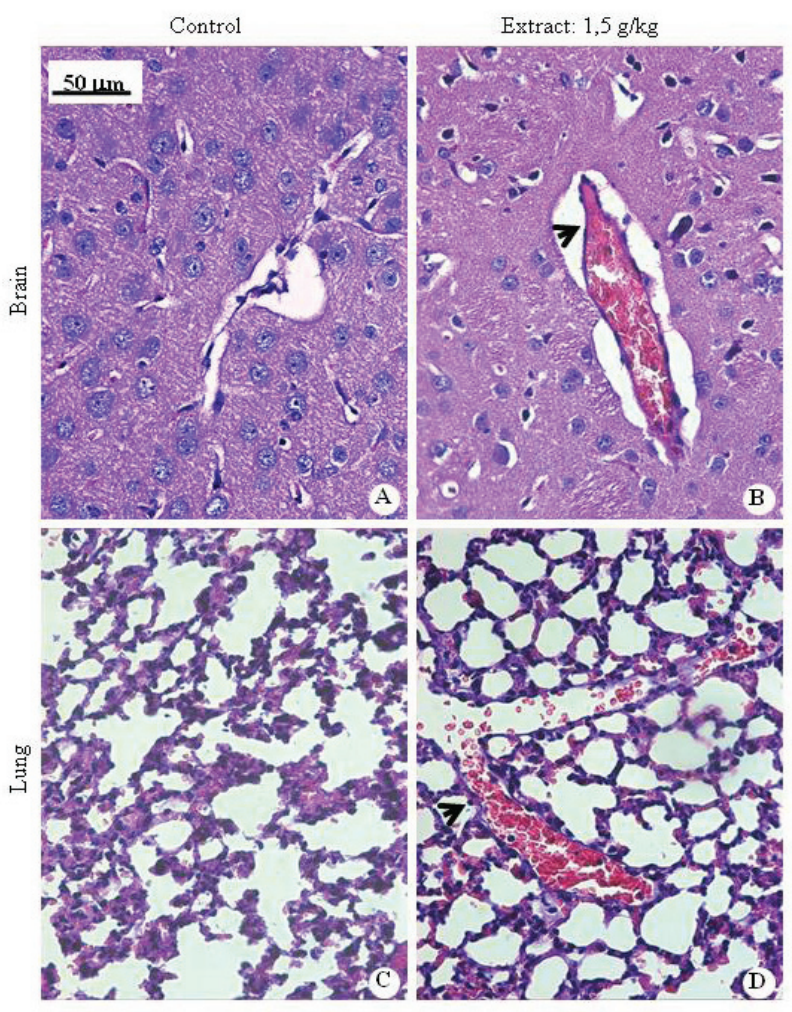

Figure 2. Photomicrographs of brain and lungs of mice subjected to toxicity study of the crude ethanol extract of Lychnophora trichocarpha. A and C: control group showing normal histopathology; B and D: animals treated with $L$. trichocarpha showing brain and lung congestion (arrowheads). Hematoxylin-eosin, Bar $=50 \mu \mathrm{m}$.

reduced locomotion in open field method (Cerqueira et al., 1987). Another study that investigated L. ericoides and L. tricocarpha also showed that these species reduced locomotor activity of animals in the open field test at doses of $1.50 \mathrm{~g} / \mathrm{kg}$ and 0.75 and $1.50 \mathrm{~g} / \mathrm{kg}$ respectively (Guzzo et al., 2006).

Changes in animals locomotion of and rearing number of observed for the highest dose of the first experimental protocol $(0.75 \mathrm{~g} / \mathrm{kg})$ and the severe toxic effects, such as reduced motility with paralysis of the hind legs, indicates CNS toxicity. The histopathology study confirmed CNS damage caused by the highest dose of the extract, since brain congestion was observed for almost all animals.

The exact mechanism by which $L$. trichocarpha extract acts on CNS is unknown. Previously, the isolated constituents from the L. trichocarpha are the sesquiterpene lactones lychnopholide and eremantholide $\mathrm{C}$, the steroids sitosterol and stigmasterol, the triterpenes friedelin, lupeol, $\alpha$-amyrin and $\beta$-amyrin, hydrocarbon mixtures, aliphatic ester mixtures, glucose, mannose, arabinose and xylose (Saúde et al., 1998).

Some sesquiterpenes lactones are known 
to cause neurotoxicity, leading to a clinical picture dominated by epileptiform convulsions followed by death through exhaustion or respiratory paralysis and asphyxia (Schmidt, 1999). However, CNS toxicity of furanoheliangolide sesquiterpene lactones, such as lychnopholide and eremantholide $\mathrm{C}$, had not yet been described.

Aminotransferases (AST and ALT), alkaline phosphatase and total protein were also measured in order to evaluate the potential hepatotoxicity of the extract. The enzymes AST and ALT can indicate cell damage in short or long-term. ALT, a cytoplasmic enzyme, is most prevalent in the acute phase and is mainly released in situations of mild hepatocellular injury (Lima et al., 1985; Gella, 1994; Kew, 2000). On the other hand, AST, which is predominantly localized in mitochondria (Kew, 2000), prevails in the chronic toxic phase and its release is caused by serious injury, raising the ratio AST/ALT (Lima et al., 1985). Alkaline phosphatase is a liver enzyme used as an indicator of cholestasis, i.e., disruption of bile flow (Motta, 2003).

One must consider that changes in these parameters occur relatively slowly and the time of the experiment may not reflect the actual toxicity to the kidneys.

In this study, the L. trichocarpha extract did not cause changes in biochemical parameters analyzed. However, histopathological alterations were observed in liver and kidneys. Brain and liver congestion suggest that the severe symptoms of toxicity observed, as well as their quick death, are probably related to acute damages in brain and lungs.

\section{Conclusion}

The results of this study suggest that the species $L$. trichocarpha is potentially toxic to liver and kidneys, which indicates risks associated with its systemic use. However, additional studies are needed to establish whether the oral route is safe or not for population. Further studies focused on the elucidation of the mechanisms by which substances found in $L$. trichocarpha extract can cause toxicity also are worthy of being performed.

\section{Acknowledgements}

The authors would like to thank Fapemigprojeto CDS 689/05; Rede Toxifar/Fapemig and CNPq companies for financial support. The authors would also like to thank João E. Guimarães, Luciana Guzzo, Simone Aparecida Ferreira, Dr. Maria Ruth Gonçalves Gaede Carrilo, Dr. Angélica Alves Lima, Dr. Célia Maria Correa, Adão Júlio da Conceição and Wilson Silvestre Vicente for collaboration.

\section{References}

Anvisa 2004. Resolução no 90 de 16/03/2004. Ministério da Saúde, Secretaria de Vigilância Sanitária. Diário Oficial da União, 18 Mar 2004.

Azevedo AO 2004. Caracterização farmacológica dos efeitos antinociceptivo e antiinflamatório do extrato hidroalcóolico bruto de Lychnophora pinaster (Arnica mineira). Biomonitoramento farmacológico da triagem fitoquímica. Dissertação de Mestrado-Programa de PósGraduação em Fisiologia e Farmacologia - Universidade Federal de Minas Gerais, 113 p.

Canalle R, Burim RV, Lopes JLC, Takahashi CS 2001. Assessment of the cytotoxic and clastogenic activities os the sesquiterpene lactone lychnopholide in mammalian cells in vitro and in vivo. Cancer Detect Prev 25: 93-101.

Cerqueira MBS, Souza JT, Júnior RA, Peixoto ABF 1987. Ação analgésica do extrato bruto aquoso liofilizado do caule e folhas de Lychnophora ericoides Mart. Cien Cult 39: 551-553.

Denenberg, VH 1969. Open-field behavior in the rat: what does it mean? Ann NY Acad Sci 159: 852-859.

Ferraz Filha ZS, Lombardi JA, Guzzo LS, Saúde-Guimarães DA 2012. Brine shrimp (Artemia salina Leach) bioassay of extracts from Lychnophoriopsis candelabrum and different Lychnophora species. Rev Bras Pl Med. In press.

Gella J 1994. Enzimologia clinica. In: Sastre FG. Bioquímica clinica. Barcelona, p. 113-124.

Guzzo LS, Azevedo MM, Saúde-Guimarães DA, GrabeGuimarães A 2006. Avaliação da atividade sobre o SNC do extrato das partes aéreas de Lychnophora ericoides Mart. In: XXI Reunião Anual da FeSBE, Águas de Lindóia. Anais da XXI Reunião Anual da FeSBE.

Guzzo LS, Saúde-Guimarães DA, Silva ACA, Lombardi JA, Guimarães HN, Grabe-Guimarães A 2008 Antinociceptive and antiinflammatory activities of ethanolic extracts of Lychnophora species. $J$ Ethnopharmacol 116: 120-124.

Hörmann HP, Korting HC 1995. Allergic acute contact dermatitis due to Arnica tincture self-medication. Phytomedicine 4: 315-317.

Kew MC 2000. Serum aminotransferase concentration as evidence of hepatocellular damage. Lancet 355: 591592.

Kupchan SM, Eakin MA, Thomas AM 1971. Tumor Inhibitors. 69. Structure-Cytotoxicity Relationships among the Sesquiterpene Lactones. J Med Chem 14: 1147-1152.

Lima AO, Soares JB, Greco JB, Galizzi J, Cançado JR 1985. Métodos de Laboratório Aplicados à Clínica-Técnica e Interpretação, $6^{\text {a }}$ ed.,Guanabara Koogan, RJ.

Motta VT 2003. Bioquímica Clínica para o Laboratório: Princípios e Interpretações, 419. Editora Médica Missau, Caxias do Sul. 
National Institutes of Health, 1985. Public Health Service. Guide for the care and use of laboratory animals. NIH publication; No. 86-23. Bethesda, NIH.

Ozturk Y, Aydine S, Ben R, Baser KHC 1996. Behavioural effects of Hypericum perforatum L. and Hypericum calcinum L. extracts of the central nervous system in mice. Phytomedicine 3: 139-146.

Prut L, Belzung C 2003. The open field as a paradigm to measure the effects of drugs on anxiety-like behaviors: a review. Eur J Pharmacol 463: 3-33.

Rodríguez M, Sosa J, Hernández G 1984. Mas, M. Pinela lindols and testosterone affect exploratory activity in male rats. Experientia 40: 397-398.

Rudzik AD, Hester JB, Tang AH, Staw RN, Friis W 1973. The Benzodiazepines. Raven press, New York.

Saúde DA, Raslan DS, Souza Filho JD, Oliveira AB 1998. Constituents from the aerial parts of Lychnophora trichocarpa. Fitoterapia 69: 90-91.

Saúde-Guimarães DA 1998. Transformações químicas, microbiológicas e atividades biológicas de lactonas sesquiterpênicas, UFMG, Belo Horizonte, MG. Tese de Doutorado em Química.

Schmidt TJ 1999. Toxic activities of sesquiterpene lactones: structural and biochemical aspects. Curr Org Chem 3: 577-608.

Tjølsena A, Bergec OG, Hunskaarb S, Roslanda JH, Holea K 1992. The formalin test: an evaluation of the method. Pain 51: 5-17.

Turner RA 1972. Screening procedures in pharmacology. New York: Academic Press.

Veiga Júnior WF, Pinto AC, Maciel MAM 2005. Plantas Medicinais: cura segura? Quim Nova 28: 519-528.

\section{*Correspondence}

Dênia A. Saúde-Guimarães

Departamento de Farmácia, Escola de Farmácia, Universidade Federal de Ouro Preto

Rua Costa Sena, 171, Centro, 35.400-000 Ouro Preto-MG, Brazil

saude@ef.ufop.br

Tel.: +553135591031

Fax: +553135591628 